\title{
Surveys of tabanid flies in the early stage of the dry season in Nigeria ${ }^{1)}$
}

\author{
Hirofumi Hayakawa, ${ }^{2)}$ Mamoru Watanabe") and Hirosi Takahasi ${ }^{4)}$ \\ "Department of Animal Production, Tohoku National Agricultural Experiment Station, \\ Morioka 020-01, Japan \\ 3) Toyama Institute of Health, Kosugi-cho, Toyama 939-03, Japan \\ 4) Hayamiya 1-40-11, Nerima-ku, Tokyo 176, Japan
}

(Received: November 24, 1988)

Key words: Tabanidae, faunal composition, larval habitat, daily activity, Nigeria.

\begin{abstract}
At the Jos Plateau in Nigeria 11 species of tabanid flies belonging to 6 genera were recorded by collecting adults and larvae. Haematopota pallidipennis and Chrysops distinctipennis were dominant at the early stage of the dry season. $C$. distinctipennis was regarded as a candidate vector of loiasis in the area. Three patterns of daily biting activity were seen in tabanid flies in the rain forest; crepuscular activity in Ha. guineensis, midday activity in Tabanus conformis and $T$. secedens, and daytime actively in $T$. besti. Parous rate of the flies was extremely high in $C$. distinctipennis, Ha. guineensis and Ha. pallidipennis. This result suggests a possibility of autogeny.
\end{abstract}

\section{INTRODUCTION}

Regarding tabanid flies in Nigeria, recent studies have witnessed significant advances in knowledge of their taxonomy and ecology as well as epidemiology as a vector of loiasis (Hori et al., 1984, 1986; Inaoka et al., 1988a, b). However, the area so far studied has been mostly confined to the rain forest where the vector species of Chrysops occur. The distribution of loiasis in Nigeria extends to the highlands of the Jos Plateau (Ufomadu et al., 1986), but little is known of tabanid

1) This study was supported by the University of Jos, Nigeria, and Japan International Cooperation Agency (JICA).

2) 早川博文: 農林水産省東北農業試験場畜産部 (平020-01 盛岡市下厨)川字赤平 4)

3) 渡辺 護：富山県衛生研究所（干939-03 富山県 射水郡小杉町中大閤山 17-1)

4) 高橋 弘：（干176 東京都練馬区早宮 1-40-11） flies in the area.

The present paper deals with the results of surveys which were carried out at the Jos Plateau in Nigeria in the early stage of the dry season in 1986 with a supplementary survey in 1987 in order to clarify the faunal composition of tabanid flies in the region. The daily biting activity of the flies was also studied in the rain forest in Nigeria.

\section{Study Areas and Method}

Surveys at the Jos Plateau. The study area is at an elevation of $800-1,500 \mathrm{~m}$ above sea level about $80 \mathrm{~km}$ from Jos City. The vegetation is typically of northern Guinea savanna. The adults of tabanid flies which flew to man, vehicle and cattle were collected by a hand net during survey of the breeding sites of black flies in the fields at 2 to 3 days intervals from late September to early December in 1986. The period is during the 
early stage of the dry season in Nigeria. The larvae were digged out by hand trowel from muddy ground, water edge and streams at as many places as possible during the same season. The larvae were reared in the laboratory for identification by the emerged adults. A supplementary survey of adults and larvae was carried out in early May in 1987.

Surveys at Igbin Hitachi Power Site. The place is located near Efe, Lagos State at a distance of $50 \mathrm{~km}$ from Lagos City. The vegetation is typically of the rain forest. The daily biting activity of tabanid flies was studied at open spaces by the side of a riverine forest at $500 \mathrm{~m}$ inland from a lagoon. The flies which attracted to exhaust of a vehicle with $4,000 \mathrm{ml}$ engine in idling were collected by a hand net successively for $30 \mathrm{~min}$ at every hour from 6:00 to 19:00 on November 25, 1986 , with a preliminary survey on the previous day. Weather condition was measured during the study. The flies, including the ones collected at the Jos Plateau, were dissected to check the physiological status.

\section{Results and Discussion}

\section{Faunal composition of tabanid flies at the Jos Plateau}

The survey result on adults is shown in Table 1. A total of 96 individuals including
10 species belonging to 6 genera were collected in the early stage of the dry season at the Jos Plateau. These flies were all females except for one male of Hybomitra chevalieri. Haematopota pallidipennis and Chrysops distinctipennis were dominant, comprising 65.6 and $16.7 \%$ of the total flies, respectively. Both species were collected from late September when the surveys were started till late November for the longest period among the species, but other species were collected for a short period of less than one month. The largest number of species and individuals was recorded in late October, but no tabanid flies were collected in early December. The species which attacked man were $H a$. pallidipennis and $C$. distinctipennis, although the latter was a more persistent blood-sucker than the former, and attacked mainly lower parts of the body.

The survey result on larvae is shown in Table 2. A total of 125 individuals including 11 species belonging to 5 genera were collected. Among them, 3 species remained unidentified because of failure in rearing. Tabanus biguttatus which was very few in adults were collected in largest numbers in larvae, but $H a$. pallidipennis which was most abundant in adults was not collected in larvae, although there is a possibility of $\mathrm{Ha}$. sp. corresponding to this species. This kind of

Table 1 Adults of tabanid flies collected at the Jos Plateau in the early stage of the dry season in 1986.

\begin{tabular}{|c|c|c|c|c|c|c|c|c|c|}
\hline \multirow{3}{*}{ Species } & \multirow{3}{*}{$\begin{array}{l}\text { No. of adults } \\
\text { collected }\end{array}$} & \multicolumn{8}{|c|}{ Occurrence season* } \\
\hline & & \multirow{2}{*}{$\frac{\text { Sep. }}{\mathrm{L}}$} & \multicolumn{3}{|c|}{ Oct. } & \multicolumn{3}{|c|}{ Nov. } & \multirow{2}{*}{$\frac{\text { Dec }}{\mathrm{E}}$} \\
\hline & & & $\mathrm{E}$ & $\mathbf{M}$ & $\mathrm{L}$ & $\mathrm{E}$ & $\mathbf{M}$ & $\mathrm{L}$ & \\
\hline Chrysops distinctipennis & 16 & 1 & 2 & 1 & 7 & 3 & 1 & 1 & \\
\hline Ancara fasciata & 2 & & & & & & 2 & & \\
\hline Hybomitra chevalieri & 1 & & & & & & & 1 & \\
\hline Atylotus agrestis & 2 & & & & & & 1 & 1 & \\
\hline Tabanus nyasae & 4 & & 1 & 2 & 1 & & & & \\
\hline T. gratus & 2 & & & & 1 & & & 1 & \\
\hline T. medionotatus & 2 & & & & 2 & & & & \\
\hline$T$. biguttatus & 1 & 1 & & & & & & & \\
\hline Haematopota pallidipennis & 63 & 3 & 2 & 4 & 45 & 8 & & 1 & \\
\hline Ha. decora & 3 & & & & 1 & 1 & 1 & & \\
\hline Total & 96 & 5 & 5 & 7 & 57 & 12 & 5 & 5 & \\
\hline (Species) & $(10)$ & (3) & (3) & (3) & (6) & (3) & (4) & (5) & \\
\hline
\end{tabular}

* E, early; M, middle; L, late. 
Table 2 Larvae of tabanid flies collected at the Jos Plateau in the early stage of the dry season in 1986.

\begin{tabular}{|c|c|c|c|}
\hline \multirow{2}{*}{ Species } & \multirow{2}{*}{$\begin{array}{l}\text { No. of larvae } \\
\text { collected }\end{array}$} & \multicolumn{2}{|c|}{ Breeding site } \\
\hline & & Pond & Stream \\
\hline Chrysops distinctipennis & 26 & 10 & 16 \\
\hline C. longicornis & 2 & 2 & \\
\hline Ancara fasciata & 2 & 2 & \\
\hline Atylotus agrestis & 4 & 4 & \\
\hline Tabanus nyasae & 8 & 6 & 2 \\
\hline$T$. gratus & 14 & 14 & \\
\hline$T$. biguttatus & 49 & 41 & 8 \\
\hline T. sp. 1 & 7 & 7 & \\
\hline$T$. sp. 2 & 3 & 3 & \\
\hline Haematopota decora & 8 & 8 & \\
\hline Ha. sp. & 2 & 2 & \\
\hline $\begin{array}{c}\text { Total } \\
\text { (Species) }\end{array}$ & $\begin{array}{l}125 \\
(11)\end{array}$ & $\begin{array}{c}99 \\
(11)\end{array}$ & $\begin{array}{l}26 \\
(3)\end{array}$ \\
\hline
\end{tabular}

discrepancy was mainly caused by the difficulty of finding specific larvae in different habitats. $C$. longicornis was recorded only in larvae. All of the species in larvae bred in ponds which were formed during the rainy season. Among them $C$. distinctipennis, $T$. nyasae and $T$. biguttatus were collected from streams as well.

In a supplementary survey no tabanid flies were collected in adults and larvae. The time was just at the end of the dry season, and most of the larval habitats which were surveyed in the previous year had dried up completely. The larvae of $T$. biguttatus was reported to make mud cylinders in the dry season as adaptation to the drying of the habitat (Oldroyd, 1954). However, such evidence was not detected in spite of great efforts in searching. Whether the larvae of tabanid flies could tolerate desiccation or whether they died out during the dry season in this area remained unsolved. $C$. silaceus and $C$. dimidiatus which are the main vector of loiasis in the rain forest (Davey and O'Rourke, 1951) were not collected at all at the Jos Plateau. Larval habitats for these species (Hori et al., 1986) were rather limited in the savanna vegetation of this area. Instead, $C$. distinctipennis which is a savanna species and a vector of loiasis in the southern Sudan (Oldroyd, 1957; Woodman and

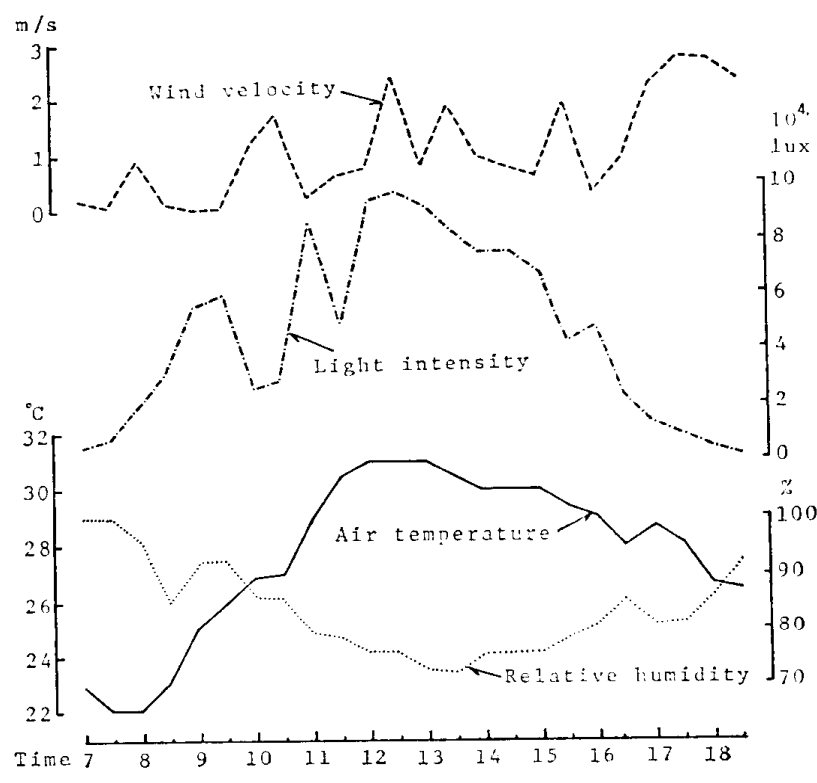

Fig. 1 Weather conditions on the day of survey (November 25, 1986) at the Igbin Hitachi Power Site.

Bokhari, 1941) was dominant in the present survey. Therefore, $C$. distinctipennis was regarded as a candidate vector of the disease at the Jos Plateau as well.

2. Daily biting activity of tabanid flies in the rain forest

Weather conditions on the day of survey are shown in Fig. 1. Although it was partly 


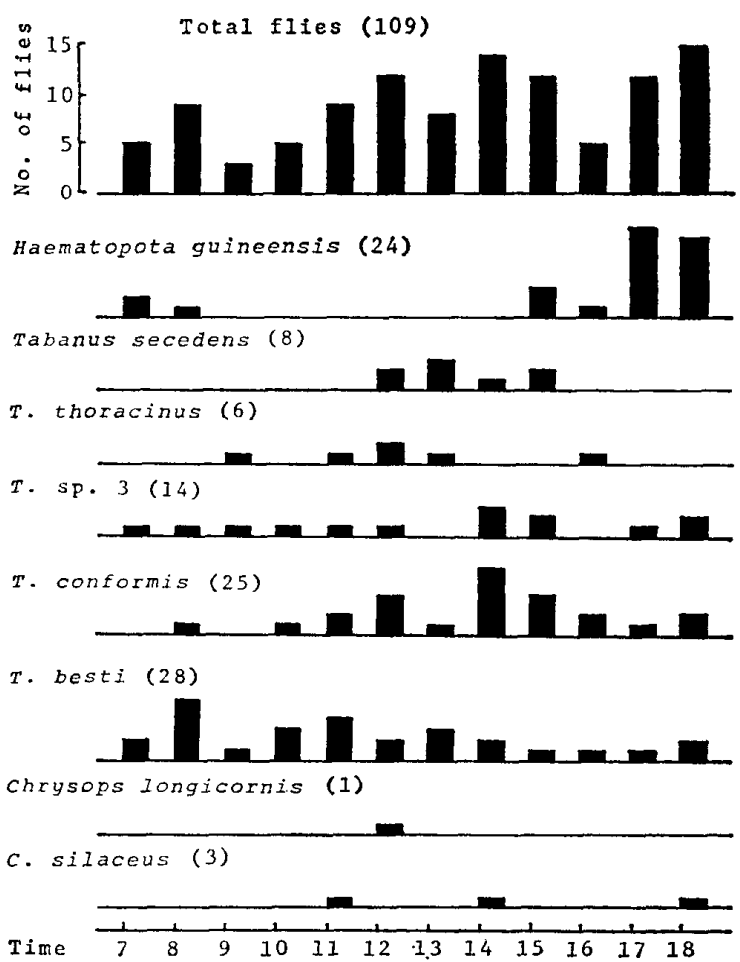

Fig. 2 Daily biting activities of tabanid flies (November 25, 1986) at the Igbin Hitachi Power Site.

Number of flies collected is shown in parenthesis.

cloudy between $8: 00$ and 10:00, the weather was rather fine and stable all day long with air temperature $22.0-32.0^{\circ} \mathrm{C}$, relative humidity more than $72 \%$, wind velocity less than $2.8 \mathrm{~m} / \mathrm{sec}$ and light intensity 95,000 lx at the maximum, typical of the season in the area. Sunrise was at $6: 40$ and sunset at 19:00.

Tabanid flies collected are shown in Fig. 2. A total of 109 individuals including 8 species belonging to 3 genera were collected. These flies were all females. $T$. besti was most abundant, comprising $25.7 \%$ of the total flies, followed by $T$. conformis $(22.9 \%)$, Ha. guineensis $(22.0 \%), T$. sp. $3(12.8 \%)$ and others $(16.6 \%)$. T. sp. 3 represents a new species in $T$. conformis-congoensis group (pers. comm. J. E. Chainey). Only 3 individuals of tsetse flies were recorded during the study, very scarce compared to tabanid flies.

On the whole, tabanid flies were active from dawn to sunset with a tendency to increase slightly in the afternoon. However, daily activity of respective species was grouped into 3 patterns. 1) Crepuscular activity: the activity is enhanced at dawn and in the evening, typically seen in $\mathrm{Ha}$. guineensis. 2) Midday activity: peak activity appears at around noon, seen in $T$. secedens, $T$. thoracinus and $T$. conformis. 3) Daytime activity: activity lasts during the day, seen in $T$. sp. 3 and $T$. besti. The studies on the biting activity of tabanid flies in Nigeria have been so far focused on Chrysops species (Duke, 1955). However, C. silaceus which is a main vector of loiasis in the rain forest was not abundant at the study site.

As for biting behavior, interesting differences were seen among the species. When observed on the vehicle, the preference site for biting was mostly sides in $C$. silaceus, sides and roof in $\mathrm{Ha}$. guineensis, and mainly inside in $C$. longicornis, $T$. secedens and $T$. thoracinus. On the other hand, $T$. conformis and $T$. besti attacked the underside. When biting on man this kind of specific behavior was also seen among the flies, but there was lack of definite observation in the present study. Workers engaged in construction of the power station were said to be suffering heavy bites by unknown flies. It was revealed that many tabanid flies includnig $C$. silaceus were present and active in the daytime throughout the day at this site.

\section{Physiological status of tabanid fies}

Dissection result of the flies which were collected in biting activity is shown in Table 3. Parous rate which was judged on the presence of relics in the ovarioles was $100 \%$ in $C$. distinctipennis and Ha. guineensis, and $96.7 \%$ in $\mathrm{Ha}$. pallidipennis. These specimens also possessed residual eggs in rather high rate compared to the others. This result suggests a possibility of autogeny in these species, because autogenous species in general become strong bloodsuckers after the first oviposition without blood meals, resulting in extremely high parous rate (Hayakawa, 1980).

All of the species were more or less nectarfed, showing $100 \%$ in $\mathrm{T}$. thoracinus and $\mathrm{Ha}$. guineensis, but the blood-fed specimens were very rare, showing $3.3 \%$ in $\mathrm{Ha}$. pallidipennis only. The number of ovarioles which denote the potential number of eggs to be laid was around 220 in C. distinctipennis, Ha. guine- 
Table 3 Dissection results of tabanid flies collected in the early stage of the dry season in Nigeria.

\begin{tabular}{|c|c|c|c|c|c|c|c|}
\hline \multirow[b]{2}{*}{ Species } & \multirow{2}{*}{$\begin{array}{c}\text { No. of } \\
\text { flies } \\
\text { sampled }\end{array}$} & \multicolumn{4}{|c|}{$\%$ flies with } & \multicolumn{2}{|c|}{ No. of ovarioles } \\
\hline & & $\begin{array}{l}\text { Follicular } \\
\text { relics }\end{array}$ & $\begin{array}{c}\text { Residual } \\
\text { eggs }\end{array}$ & Nectar-fed & Blood-fed & Min.-Max. & Mean \\
\hline Chrysops distinctipennis & 5 & 100 & 20.0 & 40.0 & 0 & $184-305$ & 249 \\
\hline Tabanus secedens & 6 & 0 & 0 & 30.0 & 0 & $782-886$ & 825 \\
\hline$T$. thoracinus & 4 & 75.0 & 0 & 100 & 0 & $645-768$ & 702 \\
\hline$T$. besti & 19 & 78.9 & 10.5 & 100 & 0 & $382-520$ & 468 \\
\hline$T$. sp. 3 & 11 & 18.2 & 0 & 81.8 & 0 & $276-475$ & 368 \\
\hline Haematopota guineensis & 22 & 100 & 13.6 & 100 & 0 & $146-266$ & 208 \\
\hline Ha. pallidipennis & 30 & 96.7 & 20.0 & 53.3 & 3.3 & $150-317$ & 232 \\
\hline
\end{tabular}

ensis and $H a$. pallidipennis, $360-830$ in Tabanus species. The number of eggs in $C$. distinctipennis which were collected in the field (Hori et al., 1984) corresponds well to those figures of ovarioles examined by dissection.

\section{ACKNOWLEDGEMENTS}

The authors are grateful to Mr. J. E. Chainey of the British Museum (Natural History) for the identification of tabanid flies collected in Nigeria, and to Dr. T. Suzuki, Medical Doctor of the Japan Embassy in Nigeria and Dr. Y. Saito of Igbin Hitachi Power Station for their great support with the study.

\section{REFERENCES}

Davey, J. T. and O'Rourke, F. J. (1951): Observations on Chrysops silacea and $C$. dimidiata at Benin, southern Nigeria. Part III. Ann. Trop. Med. Parasitol., 45: 101-109.

Duke, B. O. L. (1955): Studies on the biting habits of Chrysops. I. The biting-cycle of Chrysops silacea at various heights above the ground in the rain-forest at Kumba, British Cameroons. Ann. Trop. Med. Parasitol., 47: 340-343.

Hayakawa, H. (1980): Biological studies on Tabanus iyoensis group of Japan, with special reference to their blood-sucking habits (Diptera, Tabanidae). Bull. Tohoku Natl. Agric. Exp. Stn., 62: 131-321.

Hori, E., T. Amano, T. Inaoka, K. Yamaguchi, R. Maeda, M. Watanabe, M. Takaoka, Y. Yoneyama and E. O. Ogunba (1986): Taxonomical and Ecological Studies on Blood-Sucking Tabanids as a Vector of Loiasis in Nigeria, 40 pp., Dept. Parasitol., Saitama Medical School, Moro- yama-machi, Saitama.

Hori, E., T. Inaoka, M. Watanabe, K. Yamaguchi, Y. Yoneyama, T. Amano, M. Takaoka and E. O. Ogunba (1984): Report of the Overseas Scientific Surveys in 1980 and 1982-Taxonomical and Ecological Studies on Blood-Sucking Tabanids as a Vector of Loiasis in Nigeria, 61 pp., Dept. Parasitol., Saitama Medical School, Moroyama-machi, Saitama (in Japanese with English summary).

Inaoka, T., E. Hori, E. O. Ogunba, M. Watanabe, K. Yamaguchi, Y. Yoneyama, T. Amano, M. Takaoka and R. Maeda (1988a): Morphological characteristics of the anal segment in the identification of the larvae of Tabanus-species (Diptera, Tabanidae) collected from Nigeria. Jpn. J. Sanit. Zool., 39: 277-282.

Inaoka, T., E. Hori, K. Yamaguchi, M. Watanabe, Y. Yoneyama and E. O. Ogunba (1988b): Morphology and identification of Chrysops larvae from Nigeria. Med. Vet. Entomol., 2: 141152.

Oldroyd, H. (1954): The Horse-Flies (Diptera: Tabanidae) of the Ethiopian Region, Vol. 2, 341 pp., Br. Mus. (Nat. Hist.), London.

Oldroyd, H. (1957): The Horse-Flies (Diptera: Tabanidae) of the Ethiopian Region, Vol. 3, 489 pp., Br. Mus. (Nat. Hist.), London.

Ufomadu, G. O., G. O. C. Ekejindu, I. Tada, K. Shiwaku and B. E. B. Nwoke (1986): Acid phosphatase variations in the microfilariae of Dipetalonema perstans and Loa loa from the Jos Plateau, Nigeria. Jpn. J. Parasitol., 35: 279-286.

Woodman, H. M. and A. Bokhari (1941): Studies on Loa loa and the first report of Wuchererica bancrofti in the Sudan. Trans. R. Soc. Trop. Med. Hyg., 35: 77-92. 
Jpn. J. Sanit. Zool.

摘 要

$$
\text { ナイジェリアの乾季初期における }
$$$$
\text { アブ類の調查 }
$$

ナイジェリアのジョス高地に打けるアブ類成虫と幼 虫の調查により，6属11種が記録された. 乾季初期の 優位種は Haematopota pallidipennis と Chrysops distinctipennis であった，後者は，この地城における ロア采状虫症の媒介種と見なされた。雨林地域におけ る成虫の調査により, 日周期活動性に三つの型が認め られた. 薄明薄暮活動性は Ha. guineensis, 真尽活動 性は Tabanus conformis と T. secedens, 尽間活動性 は $T$. bestiで見られた.経産率は $C$. distinctipennis， Ha. guineensis, Ha. pallidipennis できわめて高く, これらの種では無吸血産卵の可能性が示唆された。 